\title{
THE CULTURAL (RE)TURN IN JAPANESE LAW STUDIES*
}

\author{
Luke Nottage*
}

Commemorating Professor Tony Angelo's tireless efforts and multiple achievements in translating legal rules, principles and cultures from abroad, including many from Japan, this article focuses on an ongoing project to translate selected works of a leading Japanese legal sociologist, Professor Takao Tanase. Part 2 locates Tanase's critical "hermeneutical" understanding of law and society, or of facts and norms, within various paradigms in the English-language world of "Japanese Law". These include a first wave of culturalist approaches; a model instead emphasising the institutional barriers to invoking the law in Japan; another model emphasising "elite management"; and a very different "economic analysis" of Japanese law-related behaviour. Tanase's work instead joins an emerging "hybrid paradigm" that takes more seriously new understandings and measures of culture 'project. As Tony taught us only too well, interpreting foreign legalese can be hard enough. But the most difficult task often lies in conveying the way it is embedded in a broader socio-legal praxis and discourse abroad. These challenges will not go away even in our globalised world, thereby securing the future for comparative socio-legal scholarship.

\section{TOKELAU, TEFU-TEFU, AND TRANSLATIONS}

My first and very memorable encounter with Professor Anthony Angelo - "Tony", to so many of us - was as a first-year law and commerce student at Victoria University of Wellington (VUW). In 1985 (BP - Before Powerpoints), he co-taught us the then-compulsory course in "Law in Society" by projecting slides of his photos taken on the tiny atolls of Tokelau, thus enlivening the readings about social ordering in that and other exotic communities around the world. ${ }^{1}$ This made that course

\# $\quad$ Part 2 is an updated and revised version of Luke Nottage "Translating Tanase: Challenging Paradigms of Japanese Law and Society (2006) Sydney Law School Research Papers http://ssrn.com/abstract=921932 (accessed 22 October 2008). Particular thanks to Kent Anderson, Harald Baum, Wan Sang Lung, Geoff McLay, Harry Scheiber and Leon Wolff.

* Associate Professor, Sydney Law School; Program Director (Comparative and Global Law), Sydney Centre for International Law; Co-Director, Australian Network for Japanese Law.

1 I am not alone in remaining intrigued by this non-self-governing territory administered by New Zealand, where two referendums on self-determination since 2004 have failed to attract the necessary two-thirds majority. See generally the translation of one of Tony's articles, for one of Japan's leading commercially 
far more exciting than the other compulsory first-year "Legal System" course, which was focused on how to read statutes and case law, and set me already on the path to my own ongoing studies in comparative law and society.

My second main encounter came in the final years of my law degree, when I took several of his elective courses, including Comparative Law. In the first class he co-taught, Tony drew some figures on the board and asked us to guess what they meant. I was just starting to study Japanese by correspondence and had no idea. Tony explained that they represented the four Japanese hiragana characters making up the word tefu-tefu, pronounced cho-cho, for example in Japanese haiku poetry and meaning "butterfly", which we could have guessed by the curved shapes of those characters! This led seamlessly into our study of Japanese law. We drew partly on Tony's pathbreaking translation of a French textbook by a University of Tokyo law professor, Yoshiyuki Noda, often later cited simply for the argument that Japanese culture and language underpinned the fact that: "Japanese do not like law". ${ }^{2}$ That course inspired me to apply for a Japanese government scholarship to pursue postgraduate studies in law. When I learned that Kyoto University Professor Zentaro Kitagawa was to be my supervisor, Tony immediately pointed out to me that the Law Library held many of Professor Kitagawa's works. ${ }^{3}$

My third encounter with Tony was closer and of a different kind. ${ }^{4}$ In 1993, when Tony was Dean, I was pleased to accept a fractional Lecturership at VUW Law Faculty. That same year, he completed another major translation from French, of an essay by another University of Tokyo

published law journals, by a former visiting professor to VUW from the University of Tokyo (and a contributor to this Special Issue): Anthony Angelo (Kichimoto Asaka, trans) "Tokelau ni Kempo? [A Constitution for Tokelau?]" (1995) 1078 Jurisuto 94. Tony continues to apply his wide-ranging interests in comparative law to law reform in places like Tokelau: see, for example, Anthony Angelo "Contract Codes, Coral Atolls and the Kiwi Connection" in Hans-Juergen Ahrens (ed) Festschrift fuer Erwin Deutsch zum 70. Geburtstag (Carl Heymanns, Koeln, 1999) 877.

2 Yoshiyuki Noda (Anthony Angelo trans) Introduction to Japanese Law (Tokyo University Press, Tokyo, 1976) 160.

3 In particular, Zentaro Kitagawa (gen ed) Doing Business in Japan (multi-volume looseleaf, now with LexisNexis, since 1983). Professor Kitagawa turned out not only to be one of Japan's most renowned private law scholars, but also a still indefatigable proponent of introducing and comparing Japanese law in Western languages, incorporating a key sense of the "law in action". See, for example, Zentaro Kitagawa "Use and Non-Use of Contracts in Japanese Business Relations: A Comparative Analysis"' in Harald Baum (ed) Japan: Economic Success and Legal System (de Gruyter, Berlin; New York, 1997) 145, with further references.

4 But not in the sense of the movie: Close Encounters of the Third Kind (1977) via www.filmsite.org/ (accessed 20 October 2008). 
professor, on the subtle difficulties of legal translation - an ongoing challenge for comparative lawyers, even today. As Tony wrote in that work's Preface: ${ }^{5}$

The paper has a special interest because it deals not only with the problems of law translation in general but in particular with law translation involving a language [Japanese] in which the Western European concept of law was totally unknown till little over a century ago. The paper highlights the cultural aspect of law translation and gives significant insights into the traditional attitudes of Japanese to law and into the development of Japanese legal thinking. ... From the translation point of view the product in English is itself interesting because it has had to pass through two cultural dimensions to reach the present audience. Future generations of New Zealand lawyers will, it is to be hoped, be able to communicate directly with their Japanese colleagues.

More direct communication channels indeed were opened after I returned to VUW from Kyoto to teach Japanese law, amongst other topics, over 1994-7. Under Tony's leadership and presidency, I also served as founding Secretary for the New Zealand Association for Comparative Law, which in turn collaborated in editing a special issue on Japanese Law for the VUWLR. My contribution to that issue included research towards a doctorate, begun at Kyoto University under Professor Kitagawa but completed thanks to Tony's dedication and sage supervision. ${ }^{6}$ In these and other joint comparative law projects over the last 15 years, Tony has helped to ensure my work is not completely "lost in translation". ${ }^{7}$ This has involved assistance not only in finding the correct words

5 Ichiro Kitamura (Anthony Angelo trans) "Problems of the Translation of Law in Japan" (1993) VUWLR Monograph 7, i (also available via HeinOnline). The original article in French was published in (1987) 28 Les Cahiers de Droit 747, and derived from Professor Kitamura's Japanese Report on the topic of "Problems of Law Translation" at the 12th International Congress of Comparative Law held in Sydney and Melbourne in 1986.

6 Luke Nottage "Economic Dislocation in New Zealand and Japan: A Preliminary Empirical Study" (1997) 26 VUWLR 59. A related article appeared as Luke Nottage "Planning and Renegotiating Long-Term Contracts in New Zealand and Japan: An Interim Report on an Empirical Research Project" [1997] NZ L Rev 482. This material was developed into Chapter 4 of Luke Nottage "Form, Substance and Neo-Proceduralism in Comparative Contract Law: The Law in Books and the Law in Action in England, New Zealand, Japan and the US" (PhD in Law thesis, Victoria University of Wellington, 2002), which I drew on for Luke Nottage "Changing Contract Lenses: Renegotiations in English, New Zealand, Japanese, US and International Sales Law and Practice" (2007) 14 Ind J Global Legal Stud 385. Tony also encouraged and allowed me to publish an earlier version of Chapter 3 as Luke Nottage "Form and Substance in US, English, New Zealand and Japanese Law: A Framework for Better Comparisons of Developments in the Law of Unfair Contracts" (1996) 26 VUWLR 247. More recently, Tony kindly involved me in a recent conference at VUW to extend the analytical framework to developments in international contract law: Luke Nottage "Who's Afraid of the Vienna Sales Convention (CISG)? A New Zealander's View from Australia and Japan" (2005) 36 VUWLR 815.

7 Apologies, again, for the movie analogy: Lost in Translation (2003) http://www.lost-in-translation.com. For those unaware of this film, see the review (in 2004) by ANJeL Co-Director Professor Kent Anderson, at http://law.anu.edu.au/ (accessed 21 October 2008). For those who have seen the movie, you may agree that his review does not lack in "intensity". 
to express foreign legal terms, but also in how to explain seemingly entirely alien conceptual frameworks to an audience embedded within different legal and perhaps even epistemological traditions.

As a tribute to Tony particularly in the latter respect, and to seek further sage counsel from him and others about how best to proceed, this article outlines a translation project underway for the last few years. As Part 2 explains, this involves translating a selection of articles and book chapters by a leading scholar of legal sociology in Japan and world-wide: Takao Tanase, professor at Kyoto University Law Faculty from 1977 to 2007 (and subsequently at Chuo Law School in Tokyo). ${ }^{8}$ Like his colleague Professor Kitagawa, and Tony himself, Professor Tanase continues to leave a deep impression on how I approach Japanese law - and law in general.

Regrettably, only a small proportion of Tanase's prodigious and influential work in Japanese has been published in English - although that which has appeared in English is frequently cited. ${ }^{9}$ The challenge is only partly linguistic, since I have the privilege of working with a much more skilled and qualified co-translator. ${ }^{10} \mathrm{~A}$ difficulty is that Tanase is working within a rather different paradigm for interpreting law-related behaviour - at least law-related behaviour in Japan, as interpreted by mainly English-speaking legal academics. By problematising a sharp distinction between law (norms) and behaviour (social facts), Tanase appears to be going "back to the future" in the sense of re-emphasising the inter-relationships between law and community, language or culture - proposed by an earlier generation of authors like Noda, translated by Tony three decades ago. ${ }^{11}$

Nonetheless, as Part 3 explains, Japanese law studies in English over recent years reveal a significant renewed interest in such inter-relationships. The latest "cultural turn" in the social

8 I trust Tony will forgive me for focusing on the interesting work emanating from Kyoto University Law Faculty, the arch-rival to the University of Tokyo Law Faculty, where Tony had - and has - so many friends. One of the latter's Emeritus Professors, expert in legal history, has already just published his own selection of selected and translated essays. See Shiro Ishii Beyond Paradoxology: Searching for the Logic of Japanese History (Endowed Chair in "Politics and Mass Media", Graduate School of Law and Politics, University of Tokyo, Tokyo, 2007). That represents a similar attempt to overcome the still significant linguistic and disciplinary barriers between Japan and the rest of the world.

9 Especially Takao Tanase "The Management of Automobile Disputes: Automobile Accident Compensation in Japan" (1990) 24 Law \& Soc'y Rev 651. See also recently, for example, Bruce Aronson "The Brave New World of Lawyers in Japan" (2008) 21 Colum J Asian L 45 and John Gillespie "Towards a Discursive Analysis of Legal Transfers into Developing East Asia" (2008) 40 NYU J Int'l L \& Pol 657. See also more generally Malcolm Feeley "Legality, Social Research and the Challenge of Institutional Review Boards" (2007) 41 Law \& Soc'y Rev 757.

10 Namely, Associate Professor Leon Wolff, UNSW Law Faculty. Our project received funding from the Japan Society for the Promotion of Science. For assistance with the draft translations or related logistical matters, we thank also Kent Anderson, Tom Ginsburg, Hitoshi Nasu, Veronica Taylor, Melanie Trezise, and commentators or other participants in the sixth Sho Sato Conference.

11 Noda, above n 2. 
sciences is making its mark in this area of law, as in others, despite the now well-entrenched influence of the economic analysis of law. ${ }^{12}$ Tony may feel some considerable intellectual satisfaction in this ongoing shift. As a dedicated member of the comparative law community, however, I suspect he will be sufficiently content if translations of Tanase's selected essays do become available soon for public enjoyment and edification.

Meanwhile, this essay already provides a glimpse into Tanase's universe, familiar to so many in Japan. I hope it also appeals to the sometimes quirky world-view and sense of humour displayed by Tony, who loves things French as well as Japanese, by respecting the intellectual approach of a recent best-seller by a French professor of literature and practicing psychoanalyst. Pierre Bayard's recently translated book reveals how personal interconnectedness and identities can provide multiple insights into How to Talk About Books You Haven't Read. ${ }^{13}$ Likewise, this essay may encourage reflections and conversations about "Translated Books That Have Yet to Be Published".

\section{TRANSLATING TANASE}

Draft translations of Tanase's selected essays were already a centerpiece of the sixth Sho Sato Conference on Japanese Law held at UC Berkeley over 12-13 February 2005. ${ }^{14}$ The discipline of legal sociology has deep roots in Japan, drawing from studies of "law in action" encouraged by legal realists in the United States, for example, and the tradition established by Eugen Ehrlich and others in Europe before World War II. The Japanese Association of the Sociology of Law, for which Tanase served as Program Director in the early 1990s and as President from 1999 to 2002, has grown to join together around 850 members since its founding in $1947 .{ }^{15}$ This makes it one of the world's oldest and largest associations in the field, and it collaborates actively with others based elsewhere. Individual scholars in Japan have also contributed many important theoretical and empirical studies, but many have also not been readily accessible to English language readers.

12 See, for example, J Mark Ramseyer and Minoru Nakazato Japanese Law: An Economic Approach (University of Chicago Press, Chicago, 1999); Ugo Mattei Comparative Law and Economics (University of Michigan Press, Ann Arbor, 1997); and Nicholas Mercuro and Steven G Medema Economics and the Law: From Posner to Post-Modernism and Beyond (Princeton University Press, Princeton, 2006). Compare a powerful recent critique of "ultra-instrumentalism" more generally, by one of American's most well-known legal sociologists (Feeley, above n 9) and hundreds of "Law and Culture" related papers recently via www.ssrn.com/.

13 Pierre Bayard (Jeffrey Mehlman, trans) How to Talk About Books You Haven't Read (Granta Books, London, 2007). I take a calculated risk that all readers will not follow Bayard to a postmodern extreme, and therefore refuse to read the full translations of Tanase's selected works when they do get published.

14 See various commentaries at www.law.berkeley.edu/centers/ilr/pub_sho_sato_2005 (accessed 20 October 2008). Papers presented at other sessions of that conference have recently been published: Harry Scheiber and Laurent Mayali (eds) Emerging Concepts of Rights in Japanese Law (UC Berkeley - Robbins Collection, Berkeley, 2007).

15 See www.wsoc.nii.ac.jp/ (accessed 24 October 2008). 
Translations of Tanase's collected essays can therefore provide more than a window onto his thought-provoking insights. They can also offer glimpses into the vibrant world of socio-legal studies in Japan. ${ }^{16}$

Tanase's work also reflects, and contributes to, broader shifts in this field and the social sciences more generally. He has moved away from a more functional approach to the sociology of law, dating back to his doctoral studies in sociology at Harvard University in the early 1970s. Influenced also by critical philosophy and legal theory particularly in the United States, Tanase has taken a strong "interpretive turn" since around $1990 .{ }^{17}$ The core of his approach nowadays is a hermeneutical understanding of the world, in which subjects cannot be clearly separated from objects, and goals cannot be clearly separated from acts. ${ }^{18}$ This undermines more than lawyers' ethics that adopt an extreme partisan approach - prepared to take clients' expressed goals as given, and then pursuing them to the full extent of the law. ${ }^{19}$ Tanase's epistemology also results in sharp critiques of modern liberalism itself, in a broad array of legal arenas, beginning with family law. ${ }^{20}$ It then leads him to imaginative attempts to reinstate new forms of community in law and social life. ${ }^{21}$

16 For earlier overviews in English, see, for example, Frank Upham "The Sociology of Law (Japan)" (1989) 23 Law \& Soc'y Rev 879; Shozo Ota "Law and Economics in Japan: Hatching Stage" (1991) 11 Int'l Rev L \& Econ 301.

17 Compare, for example, Stephen M Feldman "The New Metaphysics: The Interpretive Turn in Jurisprudence" (1991) 76 Iowa L Rev 661.

18 Compare, for example, Ingrid Scheibler "Gadamer, Heidegger, and the Social Dimensions of Language: Reflections on the Critical Potential of Hermeneutical Philosophy" (2000) 76 Chi-Kent L Rev 853, and other articles in that Symposium special issue on philosophical hermeneutics and critical legal theory.

19 Takao Tanase "Katari to Shite no Ho Enyo - Ho no Monogatari to Bengoshi Rinri [Invoking Law as Narrative: Lawyers' Ethics and the Discourse of Law]" (1995) 111 Minshoho Zasshi 677. A draft translation of this central work was presented at the Sho Sato conference. See also Norman Spaulding "Comments on Professor Takao Tanase's 'Invoking Law as Narrative: Lawyer's Ethics and the Discourse of Law"' (2005) http://www.law.berkeley.edu/centers/ilr/pub_sho_sato_2005/spaulding.pdf.

20 Takao Tanase "Rikongo no Mensetsu Kosho to Oya no Kenri - Hikakuho Bunkateki Kosatsu [Post-Divorce Child Visitations and Parental Rights: Insights from Comparative Legal Cultures]" (1990) 712 Hanrei Taimuzu 4; (1990) 713 Hanrei Taimuzu 14. A draft translation of this further central work was presented at the Sho Sato conference.See also Ira Mark Ellman "Comparing Japanese and American Approaches to Parental Rights: A Comment on, and Appreciation of, the Work of Takao Tanase" (2005) www.law.berkeley.edu/centers/ilr/pub_sho_sato_2005/ellman.pdf (accessed 20 October 2008).

21 Despite some significant differences in origins, concerns and conclusions, Tanase's recent work selected for the proposed book thus overlaps considerably with the studies of another innovative sociologist of law, Philip Selznick at the University of California - Berkeley, where Tanase developed close connections. Compare generally Feeley, above n 9; Robert A Kagan, Martin Krygier and Kenneth I Winston (eds) Legality and Community: On the Intellectual Legacy of Philip Selznick (Rowman \& Littlefield; Berkeley Public Policy Press, Lanham; Berkeley, 2002) (especially the chapters by Krygier and Rokumoto); and 
Although Tanase's general approach and the applications revealed in his selected essays draw considerably on tensions prominent in modern liberal law in the United States, they are also heavily imprinted by his understanding of socio-legal developments in Japan. This understanding is particularly timely because of the "third wave" of legal reform underway in Japan since its economic slowdown and political fragmentation in the early 1990s. Those reforms continue in the tradition of the "reception" of modern Western law after the country was reopened to the world during the Meiji Period (1868-1912), primarily in the form of codifications derived from continental European models, and the imposition of more far-reaching democratic reforms during the United States-led Occupation (1945-1952). The current wave of reforms, spreading from commercial law into the broader civil and criminal justice systems as well as public law, aim to fully entrench a liberal rights-based democracy in Japan. In this way, on a third attempt, the project seeks to fill what Tanase describes as "the empty space of the modern" in Japanese law and society. ${ }^{22}$

Yet his work in the selected essays provides an empirically-based theoretical framework for understanding and predicting the problems that this agenda seems to be encountering. ${ }^{23}$ His comparative analysis of the United States strongly suggests that the more the ideal of subjecting social life to law is pursued, the harder it becomes to achieve, as tensions inherent to the model emerge and communities reassert themselves. Whether Japan is at, or near, such a stage remains an empirical as well as a theoretical issue. Much work also remains to be done in thinking how the tensions identified might be minimised or overcome through redesigning socio-legal institutions. ${ }^{24}$ But Tanase's recent scholarship opens up a rich new paradigm for ongoing research and policymaking.

\section{A Paradigm Shifts in Japanese Law Studies}

As innovations continue to proliferate in legislation, case law and other levels of Japan's legal system, debate is also being rekindled regarding more conventional theories or paradigms used to understand the Japanese legal system, particularly amongst outside observers. Similar

Roger Cotterrell "Selznick Interviewed: Philip Selznick in Conversation with Roger Cotterrell" (2004) $31 \mathrm{~J}$ Law \& Soc'y 291.

22 Reproduced from Takao Tanase "The Empty Space of the Modern in Japanese Law Discourse" in David Nelken and Johannes Feest (eds) Adapting Legal Cultures (Hart, Oxford, 2001) 187. At the Sho Sato conference, this was envisaged for inclusion with the translations of Tanase's other selected works.

23 Compare, for example, Leon Wolff "The Death of Lifelong Employment in Japan?" in Luke Nottage, Leon Wolff and Kent Anderson (eds) Corporate Governance in the 21st Century: Japan's Gradual Transformation (Edward Elgar, Cheltenham, 2008) 53.

24 See, for example, Robert A Kagan "On the Routinization of Tort Claims: Takao Tanase's 'The Management of Disputes"' (2005) www.law.berkeley.edu/centers/ilr/pub_sho_sato_2005/kagan.pdf (accessed 21 October 2008). 
methodological differences now enliven the field of Japanese studies more generally. ${ }^{25}$ Among those focusing on Japanese law, a central debate has revolved around low per capita civil litigation rates, compared to other similarly industrialised economies, especially in parts of Europe and the United States. ${ }^{26}$

One of the earliest paradigms was strongly "culturalist". This derived partly from Tony's translation of Professor Noda's textbook in the 1970 s, ${ }^{27}$ an era of cultural relativism. In the US, however, the culturalist paradigm seems to have been particularly influenced by the English publications of Professor Takeyoshi Kawashima, Tanase's mentor at the University of Tokyo. ${ }^{28}$ Kawashima's death in 1992 occasioned an essay published by Tanase in a commercially-published law journal widely read in Japan. ${ }^{29}$ Tanase highlights Kawashima's explicit and implicit criticisms of the post-War perception that Japanese culture and traditions maintained an aversion to invoking and applying the law. Foreign commentators, in particular, tended to downplay Kawashima's expectation that such "laggard" social consciousness would evolve to meet the ideals set by modern law as industrialisation progressed. There may have been some justification for this quite selective reading because, as Tanase indicates, Kawashima's prediction seemed to be increasingly untenable in view of Japan's strong economic performance over the 1970s and 1980s, yet little additional

25 See, for example, Patrick Smith Japan: A Reinterpretation (Vintage Books, New York, 1998); Yoshio Sugimoto An Introduction to Japanese Society (Cambridge University Press, New York, 2003).

26 Masaki Abe and Luke Nottage "Japan" in Jan Smits (ed) Encyclopedia of Comparative Law (Edward Elgar, Cheltenham, 2005) 376, updated at www.asianlii.org/ (accessed 21 October 2008). See also Luke Nottage and Christian Wollschlaeger "What Do Courts Do?" (1996) 1996 NZLJ 369.

27 Noda, above n 2.

28 See, for example, Takeyoshi Kawashima "Dispute Resolution in Contemporary Japan" in Arthur von Mehren (ed) Law in Japan: The Legal Order in a Changing Society (Harvard University Press, Harvard, 1963) 41 and Takeyoshi Kawashima "The Legal Consciousness of Contract in Japan" (1974) 7 Law in Japan: An Annual 1 (translated by Charles Stevens). The former is part of a major conference volume, which has recently generated a follow-up volume focusing instead on Japan's current "third wave" of law reform. See Daniel H Foote Law in Japan: A Turning Point (University of Washington Press, Seattle, 2007), which I review in 25 J Japanese L 260-5 (2008) available also at www.law.usyd.edu.au/ (accessed 21 October 2008).

29 Takao Tanase "Kindai no Rinen to Yuragi - Kawashima Hoshakaigaku no Riron to Jissen [the Ideal and Unsettling of Modernity: The Theory and Practice of Kawashima's Sociology of Law]" (1993) 65 Horitsu Jiho 26. A draft translation of this work was presented at the Sho Sato conference. For another perspective, see S Miyazawa "Taking Kawashima Seriously: A Review of Japanese Research on Japanese Legal Consciousness and Disputing Behavior" (1987) 21 Law \& Soc'y Rev 219. Kitamura (above n 5, 33) sharply criticises another modernisation argument by Kawashima, namely his call for Japanese scholars to write sentences in Japanese that follow a grammatical structure as close as possible to European structure, to facilitate translation from the Japanese. He criticises this as divorcing style from local understandings and nuances, as often occurs also with Japanese translations of substantive terms. But Kitamura also criticises Kawashima for not practicing what he preached: "the concrete applications of his thesis ... are brim-full of brilliant ideas but alas sometimes also with difficult turns of phrase". 
formal engagement with the legal system. Also, as illustrated by Tanase's earlier research into outof-court resolution of traffic accident disputes, diverse social and legal actors were strategically reconfigured precisely to avoid the need to take cases through the court system. ${ }^{30}$

When aggregate per capita civil litigation rates did start to escalate, beginning with the economic slowdown prompted by the Oil Shocks in the 1970s, some remembered Kawashima's prediction. But careful commentators still remained impressed by Japan's comparatively low litigation rates, as implying an enduring broader cultural tendency to avoid formal litigation processes. ${ }^{31}$ Tanase's most recent empirical work in this area likewise points out that the rising rates are largely driven by debt collection litigation. ${ }^{32}$ This is less illustrative of burgeoning consciousness of legal rights, especially when the legal norm requiring repayment seems to mesh anyway with the "cultural" norm of repaying one's debts. However, Tanase also uncovers rises in general tort litigation, and more contentiousness even in traffic dispute resolution cases (correlated with increases in lawyer numbers and involvement). These suggest both a degree of "modernisation" of legal consciousness in Japan, and the patterning effect still of social structures and more diffuse cultural norms.

Tanase's more nuanced re-interpretation and empirical study of ongoing issues first highlighted by Kawashima and others, in English, seem to go largely against the tide generated by socio-legal studies of Japan from abroad published particularly over the 1980s and 1990s. A sharp critique of the culturalist paradigm came first from an article entitled "The Myth of the Reluctant Litigation", published by (then) University of Washington Professor John Haley. ${ }^{33}$ This highlighted the possible malleability of culture and social structures, observing that litigation rates had been higher before than after World War II. The main explanation given was that "institutional barriers" to bringing suit had been raised, by limiting the numbers of legal professionals and allowing problems in civil procedure to persist, so that fewer claimants could afford to sue and thus obtain outcomes nominally prescribed by the law. Thus, this early work by Haley established an alternative paradigm, that "the Japanese can't like law" - even if they would prefer to pursue it. His later work did become less critical of this post-War situation. Haley increasingly asserted various positive effects from retaining

30 Tanase, "The Management of Automobile Disputes: Automobile Accident Compensation in Japan", above n 9.

31 Christian Wollschlaeger "Historical Trends of Civil Litigation in Japan, Arizona, Sweden and Germany: Japanese Legal Culture in the Light of Judicial Statistics" in Harald Baum (ed) Japan: Economic Success and Legal System (de Gruyter, Berlin; New York, 1997) 89.

32 Takao Tanase "Soshoriyo to Kindaika Kasetsu [Litigation Use and the Modernisation Hypothesis]" in Yoshimitsu Aoyama et al (eds) Minjisoshoho Riron no Aratana Kochiku [New Constructions in Civil Procedure Law Theory] (Yuhikaku, Tokyo, 2001) 287. A draft translation of this work was presented at the Sho Sato conference.

33 John Haley "The Myth of the Reluctant Litigant" (1978) 4 J Japanese Stud 359. 
communitarian tendencies in socio-legal life in Japan. ${ }^{34}$ But that developed quite separately from Tanase's turn to communitarianism over the 1990s, without the latter's clear theoretical underpinnings. That may explain the more limited direct impact of Haley's later work, compared to his initial study of "institutional barriers".

Another possible reason for that study's enduring attraction is that a powerful third paradigm also grew out of Haley's early work. The "social management" paradigm refined the idea that institutional barriers could be maintained particularly by social elites in Japan, to resolve social problems outside the courts and thus minimise the possibility of society being led in unpredictable directions. Often, alternative dispute resolution procedures and resources were inaugurated to facilitate such management. More so than Haley, (then) Boston University Professor Frank Upham detailed how this management approach was embedded in a variety of areas after World War II: pollution, discrimination (against women or burakumin outcastes), and - perhaps less pervasively industrial policy. ${ }^{35}$ The early study of traffic accident dispute resolution by Tanase was often read as consistent with this paradigm too. ${ }^{36}$ In short, this third paradigm suggested instead that "the Japanese are made not to like law".

Further, just as Haley's later insights have tended to be overlooked, most commentators writing outside Japan and adopting this perspective have tended to remain critical of the management approach to socio-legal ordering, and to emphasise the heavy hand of the bureaucracy in directing the elite response. ${ }^{37}$ Yet this occurred despite Upham himself later seeming to became more circumspect, especially regarding the normative implications of the management approach. ${ }^{38}$ Even more so, Tanase's more recent work on tort law ${ }^{39}$ and the socially disadvantaged ${ }^{40}$ seeks to find a

34 John O Haley Authority without Power: Law and the Japanese Paradox (Oxford University Press, New York, 1991); John O Haley The Spirit of Japanese Law (University of Georgia Press, Athens; London, 1998).

35 Frank Upham Law and Social Change in Post-War Japan (Harvard University Press, Cambridge, 1987).

36 Tanase, "The Management of Automobile Disputes: Automobile Accident Compensation in Japan", above n 9.

37 See, for example, Anita Bernstein and Paul Fanning "'Weightier Than a Mountain': Duty, Hierarchy, and the Consumer in Japan" (1996) 29 Vand J Transnat'l L 45.

38 Frank Upham "Weak Legal Consciousness as Invented Tradition" in Stephen Vlastos (ed) Mirror of Modernity: Invented Traditions of Modern Japan (University of California Press, Berkeley, 1998) 48.

39 Takao Tanase "Fuhokoisekinin no Dotokuteki Kiso [The Moral Foundations of Tort Liability]" in Takao Tanase (ed) Gendai Fuhokoiho [Modern Tort Law: Ideals of Law and the Life-World] (Yuhikaku, Tokyo, 1994) 3. A draft translation of this work was presented at the Sho Sato conference.

40 Takao Tanase "Kenri to Kyodotai [Rights and Community]" (1997) 69 Horitsu Jiho 7; Takao Tanase "Kyodotairon to Kenpo Kaishaku [Communitarianism and Constitutional Interpretation]" (2002) 1222 Jurisuto 11. Draft translations of both works were presented at the Sho Sato conference. 
middle way. It tries to highlight and avoid both tightly structured and potentially openly oppressive solutions to complex social problems, and an individual rights-based approach that tends to mask other forms of violence. Instead, he favours more contextualised problem-solving processes through which communities can continuously redefine both themselves and the legal system.

Tanase's approach therefore directly contradicts a fourth paradigm for analysing Japanese law and society, which became increasingly popular especially in the United States over the 1990s. This "economic rationalist" paradigm takes to an extreme the idea of individuals (as litigants in civil disputes faced by institutional barriers) or elite groups (managing society) acting in their selfinterest, resulting in little litigation through the courts. The distinctive feature of this paradigm, however, is that it asserts instead that "the Japanese do like law". They rationally act in its shadow or pattern their behaviour around it. Thus, despite high barriers to bringing suit, Japanese law is predictable - at least in some areas such as traffic accident dispute resolution, and compared to countries like the United States - so claimants do not even need to file suits to be able to obtain favourable settlements out of court. ${ }^{41}$ Much recent work within this economic rationalist paradigm, championed especially by Harvard Law School Professor Mark Ramseyer, also relies on quantitative techniques in social science, particularly econometrics. ${ }^{42}$

The assumptions of crystal-clear distinctions between empirical observation and normative implications, and of prediction rather than broader understanding as the sole goal of social science, creates a major tension with Tanase's hermeneutical approach and his more eclectic methodological toolkit. Another tension arises because Ramseyer's economic rationalism nowadays implies - or at least leads to - a normative preference for minimal legal intervention in social as well as economic ordering, with such intervention moreover adopting simple bright-line rules. ${ }^{43}$ This tension becomes increasingly apparent as problems emerge with the empirical evidence emphasised by Ramseyer to prove that Japan does not display any distinctive socio-legal institutions, such as "main banks" in corporate governance, so that all can be explained by conventional market mechanisms. ${ }^{44}$

41 J Mark Ramseyer and Minoru Nakazato "The Rational Litigant: Settlement Amounts and Verdict Rates in Japan" (1989) 18 J Legal Stud 263. See generally also Ramseyer and Nakazato Japanese Law: An Economic Approach, above n 12 .

42 See especially J Mark Ramseyer and Eric Rasmusen Measuring Judicial Independence: The Political Economy of Judging in Japan (University of Chicago Press, Chicago, 2003). Interestingly, like his pupil Tanase, Kawashima is not adverse to quantitative studies per se. See, for example, Takeyoshi Kawashima "Individualism in Decision Making in the Supreme Court of Japan" in G Schubert and D Danelski (eds) Comparative Judicial Behavior: Cross-Cultural Studies of Political Decision-Making in the East and West (Oxford University Press, New York, 1969) 103.

43 Compare also Richard Epstein Simple Rules for a Complex World (Harvard University Press, Cambridge (MA) 1995).

44 Craig Freedman and Luke Nottage "You Say Tomato, I Say Tomahto, Let's Call the Whole Thing Off: The Chicago School of Law and Economics Comes to Japan" (2006) 2006-4 Centre for Japanese Economic 
Thus, the work by Tanase in his selected essays recreates broader methodological struggles within legal sociology and the social sciences more generally. In particular, it provides another foothold especially for those dubious about one true religion in understanding rapidly evolving law and society in Japan. Already, we may be witnessing the emergence of a more "hybrid" paradigm. As Part 3 elaborates below, some works within this paradigm combine both qualitative and quantitative methodologies. All generally adopt more nuanced approaches to demonstrate why and how "the Japanese sometimes like law, but sometimes don't". Many also conclude that contemporary Japan is undergoing a significant but "gradual transformation", as in other advanced industrialised democracies characterised by more coordinated market economies. ${ }^{45}$ Tanase's recent work offers rich potential particularly for these sorts of studies, and also may revive the more normative proposition that "the Japanese need not like all law".

For example, Ginsburg and Hoetker interpret their quantitative analysis as largely supporting Haley's thesis that institutional incapacity (especially low numbers of judges) governs civil litigation. Their results are also seen as going against Upham's elite management thesis (albeit on the arguable assumption that Japan's elite has not changed much since the 1990s), as well as Ramseyer's predictability thesis (although underlying substantive law has been changing rapidly in many more areas than they imply). Ginsburg and Hoetker also question one aspect of Kawashima's culturalist/modernisation thesis, by finding that urban residents (usually considered more "modern") are not statistically more likely to sue, and more broadly (developing Wollschlaeger's analysis) by emphasising the cyclical inverse correlation with economic growth. Their overall conclusion, that "Japanese appear to respond to incentives to litigate just as do citizens of other advanced industrialised democracies", still leaves open the question of whether such incentives are purely economic. ${ }^{46}$ That is contested by Tanase's own quantitative analysis, and his general hermeneutical approach to law and socio-economic ordering.

\section{B Broader Ramifications of Tanase's Work}

Tanase's work also generates much more than a controversy within a discipline like legal sociology, let alone a sub-discipline like Japanese law. Such divergent paradigms for interpreting

Studies Research Papers via www.econ.mq.edu.au/ (accessed 21 October 2008); Dan Puchniak "A Skeptic's Guide to Miwa and Ramseyer's 'The Fable of the Keiretsu'" (2007) 24 J Japanese L 272, also available via www.law.usyd.edu.au/ (accessed 21 October 2008).

45 Nottage, Wolff and Anderson Corporate Governance in the 21st Century: Japan's Gradual Transformation, above $\mathrm{n} 23$.

46 Tom Ginsburg and Glenn Hoetker "The Unreluctant Litigant? An Empirical Analysis of Japan's Turn to Litigation" (2006) 35 J Legal Stud 31, 56. Compare generally also Tanase's further recent quantitative analysis, but of citizens' attitudes towards the law (rather than their behaviour): Takao Tanase "Nihonjin no Kenrikan/Keibatsu Ishiki to Jiyushugiteki Hochitsujo [Japanese Conceptions of Rights and Attitudes Towards Punishment, and Liberal Legal Order]" (2005) 157 Hogaku Ronso 1. 
law, society and the economy have framed important policy-making processes and outcomes domestically and in other countries dealing with Japan, and no doubt they will continue to do so. ${ }^{47}$ Under the culturalist paradigm in Kawashima's variant, for example, Japan could more readily justify placing top priority on economic growth particularly over the 1960s, since the implication was that modernisation - in the sense of industrialisation - would lead to "enlightened" modernisation of legal consciousness anyway. Its trading partners, notably the United States, could go along with this too.

By the 1980s, however, the institutional barriers and social management paradigms not only identified a tension within Kawashima's theory, namely the possibility of manipulating culture or at least related social structures. Those paradigms also led to divergent views in Japan as opposed to the United States. While Japan became confident that it had turned the tension to its social and economic advantage, the Unitebecame increasingly critical about what it perceived (and sometimes certainly experienced) as the closed nature of "Japan, Inc". This standoff has lessened somewhat, as the deregulation movement - underpinning, and underpinned by, the economic rationalism paradigm - has not only maintained momentum in the United States, but also found increasing traction in Japan especially around the time of its financial crisis in the late 1990s. Nonetheless, Japanese law and society have certainly not become Americanised. ${ }^{48}$ More hybrid approaches, advanced by work like Tanase's, are likely to mean ongoing "re-regulation" and some persistent divergences in the making and implementation of socio-economic policy. ${ }^{49}$

In addition, whatever form it ends up taking, Japan's transfiguration will have important repercussions for its partners in trade, investment, security and social issues that also increasingly transcend national borders. By better understanding what is happening in Japan nowadays, we also become better placed to understand transformations world-wide. Notably, Japan maintains a very large Overseas Development Assistance budget, especially in Asia. A growing proportion is directed at "legal technical assistance" to developing countries further jolted by the Asian Financial Crisis of 1998. This raises the question of whether any distinctive Japanese views on socio-legal ordering may be "exported" anew. ${ }^{50}$

47 Luke Nottage "Redirecting Japan's Multi-Level Governance" in Klaus Hopt et al (eds) Corporate Governance in Context: Corporations, State, and Markets in Europe, Japan, and the US (Oxford University Press, Oxford, 2005) 571.

48 Compare R Daniel Kelemen and Eric C Sibbitt "The Americanization of Japanese Law" (2002) 23 U Pa J Int'l Econ L 269.

49 See, for example, Peter Drysdale and Jennifer Amyx (eds) Japanese Governance: Beyond Japan Inc (RoutledgeCurzon, London, 2003); Jennifer Amyx Japan's Financial Crisis: Institutional Rigidity and Reluctant Change (Princeton University Press, Princeton, NJ, 2004); Nottage "Who's Afraid of the Vienna Sales Convention (CISG)? A New Zealander's View from Australia and Japan", above n 6.

50 See, for example, Veronica Taylor "New Markets, New Commodity: Japanese Legal Technical Assistance" (2005) 23 Wis Int'l LJ 251. For an earlier era, see Alexis Dudden Japan's Colonization of Korea: Discourse 
Japanese firms have also developed particularly extensive bilateral trade and investment relations with the People's Republic of China. In that country's context, too, Tanase and some research associates have also begun sounding warning bells about simplistic attempts to impose a pure liberal model of law. His critical conclusions are based on sophisticated theoretical and empirical observations rooted in comparing Japan's experience. ${ }^{51}$ Specifically, addressing first China's recent reform initiatives regarding property rights, Tanase points out the parallel to the overly idealised view of rights propounded by Kawashima decades ago. ${ }^{52}$ Contrasting actual experiences subsequently in Japan (such as the pseudo-legal "administrative guidance" that limited owners' rights to develop "large-scale retail stores"), 53 as well as other countries (such as colonial Africa and the United States itself), Tanase stresses that the "exclusory" nature of property rights is socially constructed and constrained. More generally, rights are much more diffuse than Kawashima and contemporary law reformers in China believe.

Secondly, responding to China's efforts to create an independent judiciary as a centerpiece in securing the autonomy of law, Tanase argues that independence is relative not only to politics, but also to society. Yet society continually reinvents and reasserts itself, even as law (and its ideological counterpart, legalism) invades social spaces. This is evident not only in the context of the family, ${ }^{54}$ but also the economy. In contractual relationships, for example, the tension between law and society emerges for two main reasons. There are always limits to enforcement through formal court processes, so parties must call on more diffuse "credible commitments". In addition, more formalised legal rules can in fact create more scope for opportunistic "hold-ups" once a party has entered into a contract. This necessitates broader social constraints on such narrow self-interest, evident in Japanese "relational contracting". 55

and Power (University of Hawaii Press, Honolulu, 2005), which I review in (2005) Asian Stud Rev 432. More generally, see Gillespie, above n 9; and (referring to hermeneutics) John Gillespie "Rethinking the Role of Judicial Independence in Socialist Transforming East Asia" (2007) 56 ICLQ 837.

51 Takao Tanase "Gurobaru Shijo to Ho no Shinka [Global Markets and Law's Evolution]" (2003) 1258 Juristo 44; edited as "Global Markets and the Evolution of Law in China and Japan" (2005) 26(4) Mich J Int'l L 873.

52 Above n 29.

53 See also Upham, Law and Social Change in Post-War Japan, above n 35; and Frank Upham "Privatising Regulation: The Implementation of the Large-Scale Retail Stores Law" in GD Allinson and Y Sone (eds) Political Dynamics in Contemporary Japan (Cornell University Press, Ithaca, 1993) 264.

54 Above n 20.

55 See also John O Haley "Rethinking Contract Practice and Law in Japan" (2008) 1 J East Asia \& Int'l L forthcoming (and via http://ssrn.com/abstract=1131327) (accessed 20 October 2008). Compare, for example, Nottage above n 6 (especially in "Planning and Renegotiating Long-Term Contracts in New Zealand and Japan": uncovering considerable similarities in relational contract practice in New Zealand firms, despite somewhat stricter contract law regarding termination) and Ichiro Kobayashi "The Interaction between Japanese Corporate Governance and Relational Contract Practice" (2005) 2 NYU J L \& Bus 269 
As a final lesson for China that draws on comparative socio-legal studies, Tanase identifies several major direct challenges to the market principle as the primary means to order law and society. One is democracy, evidenced by moves towards more citizen participation in the judicial system. Another is social solidarity, evident for example in the European Union. And a third is sovereignty, acknowledged even by institutions like the World Bank in attempts to promote "good governance" through law reform, albeit primarily to support economic growth. ${ }^{56}$

All these are subtle but powerful arguments against those perceiving or advocating the rapid world-wide expansion of neo-liberal views on law and socio-economic ordering. They also contrast with some more emotional over-reactions we find nowadays, or more straightforward concerns raised about the practical problems likely to arise when transplanting any legal institutions into new environments. Thus, Tanase's work contributes not only to a perennial concern of historians, lawyers, legal sociologists and many other social scientists: modernity. ${ }^{57}$ It also intersects with another major issue preoccupying many of them: globalisation. ${ }^{58}$

(asserting that relational contracts have been entrenched by broader corporate governance mechanisms in Japan, but will give way to discrete contracts).

56 See also, for example, the controversy about the FDI model promoted by the World Bank's International Centre for Settlement of Investment Disputes: Luke Nottage and Kate Miles "Back to the Future for Investor-State Arbitrations: Revising Rules in Australia and Japan for Public Interests" (2008) 08/62 Sydney Law School Research Paper http://ssrn.com/abstract=1151167 (accessed 21 October 2008, forthcoming in $J$ Int'l Arb)

57 For perspectives from professors of language and of history, respectively, see Marianne Constable "Comments on the Collected Writings of Takao Tanase: Modernism" (2005) www.law.berkeley.edu/centers/ilr/pub_sho_sato_2005/constable.pdf (accessed 21 October 2008) and Andrew Barshay "Comments on the Theme of Modernism in the Work of Takao Tanase" (2005) www.law.berkeley.edu/centers/ilr/pub_sho_sato_2005/barshay.pdf (accessed 21 October 2008). On the theme of modernity addressed in broader Japanese studies recently, see, for example, Nancy Ross Rosenberger Gambling with Virtue: Japanese Women and the Search for Self in a Changing Nation (University of Hawaii Press, Honolulu, 2001); Robert Neelly Bellah Imagining Japan: The Japanese Tradition and Its Modern Interpretation (University of California Press, Berkeley; London, 2003); Ai Maeda and James A Fujii Text and the City: Essays on Japanese Modernity (Duke University Press, Durham, NC, 2004); Simon Partner Toshie: A Story of Village Life in Twentieth-Century Japan (University of California Press, Berkeley; London, 2004).

58 Ulrich Beck What Is Globalization? (Polity Press, Malden (MA) 2000); Ulrike Schaede and William W Grimes (eds) Japan's Managed Globalization: Adapting to the Twenty-First Century (ME Sharpe, Armonk (NY) 2003). Tanase's work is also deeply suggestive for analysing a parallel phenomenon, the emergence of the "information society". In Japan, see, for example, Nanette Gottlieb, Mark J McLelland and David Gauntlett (eds) Japanese Cybercultures (Routledge, London, 2003). 


\section{BACK TO THE FUTURE: BRINGING BACK CULTURE INTO JAPANESE LAW STUDIES}

To my mind, and hopefully Tony's if I reflect some of his training, "translating Tanase" is therefore a worthwhile endeavour. This has been and remains a long-term project, but it seems increasingly timely. Even compared to five years ago, there is a significant increase in the number and quality of publications in English that take culture more seriously when analysing diverse facets of Japanese law.

Attention to culture has remained a more consistent undercurrent in the scholarship on Japanese law written mainly in German for those fluent in German - the world of "Japanisches Recht". ${ }^{59}$ Yet the cultural theory invoked has tended to be remain much less sophisticated than German writers' comparisons of Japanese "black-letter law". Most English writing, primarily for those from Englishspeaking countries (the "Japanese Law" world), also more often now goes directly to the Japaneselanguage literature on Japanese law (the "nihon-ho" world). That world has always been large and diverse. Yet, precisely as free-market economics and formal-reasoning based visions of law have gained momentum since the 1990s, the nihon-ho world has arguably given more weight to critical or neo-communitarian perspectives on Japanese law. Tanase has championed such approaches consistently over this period, and their influence - directly, as well as indirectly especially via his many students (deshi) ${ }^{60}$ - may have grown as the Japanese economy finally regained momentum from 2002. The (re)turn to culture in English-language "Japanese Law" scholarship may be picking up on this new tendency, although it also reflects the shifting sands of socio-legal discourse in English-speaking academic environments.

Nonetheless, culturalist elements are reappearing in new guises, as part of the hybrid paradigm for better understanding law-related behaviour and associated epistemological frameworks in contemporary Japan. First, as mentioned briefly in Part 2 above, this is apparent in more eclectic

59 Tom Ginsburg, Luke Nottage and Hiroo Sono "The Worlds, Vicissitudes and Futures of Japan's Law" in Tom Ginsburg, Luke Nottage and Hiroo Sono (eds) The Multiple Worlds of Japanese Law (University of Victoria, BC Canada, 2001) 1. Reflecting similar origins in Japanese Studies, the study of Japanese law in countries like Belgium has also drawn on other social sciences: Dimitri Vanoverbeke "Japanese Law in the Low Countries and France" in Tom Ginsburg, Luke Nottage and Hiroo Sono (eds) The Multiple Worlds of Japanese Law (University of Victoria, BC Canada, 2001) 25. The new generation in continental Europe, however, appears more critical of broad appeals to culture. The inaugural Professor of Japanese Law at Frankfurt University, for example, takes issue with a view that Japanese statutory provisions directly reflect Japanese cultural or social norms: Moritz Baelz "Wider den Exotismus? Zur Bedeutung Der Kultur fuer das Verstaendis des Modernen Japanischen Rechts [Against Exoticism? Culture's Significance in Understanding Modern Japanese Law]" (2008) 25 J Japanese L 15.

60 Ichiro Ozaki "A Rapid Lapse from Idealism to Instrumentalism" in Harry Scheiber and Laurent Mayali (ed) Emerging Concepts of Rights in Japanese Law (UC Berkeley - Robbins Collection, Berkeley, 2007) 211, 214-15. See also an early critique by Setsuo Miyazawa "For the Liberal Transformation of Japanese Legal Culture: A Review of the Recent Scholarship and Practice" (2001) 4 J Japanese L 101. 
methodological approaches. The first wave of culturalist approaches tended to generalise from a narrow base of empirical observations, often filtered through studies in quite specific disciplines. In arguing that the Japanese do not like law because of an aversion to logic and conceptual structures, for example, Noda was inspired by some work by two French existentialist philosophers writing in the early 1960s. ${ }^{61}$ Kawashima's works in English looked at some statistical data, but interpreted them through broader theories of modernisation. ${ }^{62}$ Haley's work on institutional barriers also undertook some statistical analysis, but in aggregates, focusing then on the legal rules or institutions that collectively generated limited reported engagement of the civil justice system in Japan. ${ }^{63}$ Elite management theorists like Upham generalised instead from a series of case studies involving sets of public policy disputes, tracking the emergence of social problems and the responses by government and the legal systems. ${ }^{64}$

A big shift came from the late 1980s, when Ramseyer increasingly turned to econometric analyses of specific areas of Japanese law, to show instead that it often played significant roles in socio-economic ordering. His adoption of econometrics as a dominant modus operandi is consistent not only with Chicago School methodology, which distrusts whatever social actors say (or think), but also with the broader modernist tradition that sharply separates facts from norms - at least in theory. ${ }^{65}$ Econometric analysis also became popular among leaders of the "next generation" of American scholars of Japanese law, especially Mark West and Curtis Milhaupt. ${ }^{66}$

Especially once tenured at leading United States law schools, however, those two scholars' studies have tended to draw on a wider array of sources. West's study of karaoke noise disputes

61 Noda, above n 2, xi and 161-3 (namely Rene Le Senne and Paul Grieger, who was partly influenced by Carl Jung's work on psychological character types). He acknowledged some limitations and critiques of their work, but still tried to develop and test their hypotheses in his book, and in a later work: "Japan" in René David and others (eds) International Encyclopedia of Comparative Law (JCB Mohr, Tuebingen, 1973) Volume 2. Kitamura, above n 5, 39 was also sympathetic to Noda's hypothesis that peoples from different (legal) culture may still reflect the Jungian archetype of the collective subconscious, expressed through some universal (probably very abstract or succinct) legal principles or "proto law". In fact, there has been a recent revival of cross-cultural psychology, particularly in comparing Japanese or other East Asians, but instead mainly using controlled experiments in the behaviouralist tradition. See especially Richard Nesbitt, The Geography of Thought: How Westerners and Asians Think Differently ... And Why (Free Press, New York, 2003).

62 Kawashima "Dispute Resolution in Contemporary Japan", above n 28; and especially Kawashima (1969), above n 28.

63 See especially Haley, "The Myth of the Reluctant Litigant", above n 33.

64 Upham, Law and Social Change in Post-War Japan, above n 35.

65 Freedman and Nottage, above n 44; and Tanase, "Katari to Shite no Ho Enyo - Ho no Monogatari to Bengoshi Rinri [Invoking Law as Narrative: Lawyers' Ethics and the Discourse of Law]", above n 19.

66 Kent Anderson "The New Generation: Milhaupt and West on Japanese Economic Law" (2006) 27 Mich J Int'l L 985. 
published in 2002, for example, relied especially on qualitative data (interviews) to show how costs and other "institutional barriers" prompted neighbours to use free mediation services provided by local governments instead of suing. But he turned to quantitative analysis of "social capital", a proxy arguably for culture that had been developed by comparative political scientists, to explain why some communities preferred direct negotiations rather than escalating the disputes by invoking mediation. ${ }^{67}$ Other studies, also included in his 2005 book on Law in Everyday Japan, used further techniques like structured experiments ("drop tests", regarding Japanese citizens' responses to lost property) to show how and why law sometimes matters, but sometimes doesn't. ${ }^{68}$ For similar conclusions in his most recent book, The Rules of Scandal in Japan and the United States, West draws on legislation and court judgments, interviews, media accounts and (self-)commentary, "personal experience gained either as a lawyer or as an acquaintance of the participants", and finally "where relevant, ... sources like statistics, surveys, advice columns and stock return data". ${ }^{6}$

Milhaupt also still sometimes applies quantitative methodology, including econometrics. ${ }^{70}$ But he also conducts interviews of socio-economic actors, and is noteworthy among leading American scholars of Japanese law for his close attention to case law. ${ }^{71}$ Milhaupt also seems more interested than West in how the institutional "rules of the game" emerge in Japanese law and society, rather than how those then impact back on behaviour. Norm generation focuses more on processes,

67 Mark D West "The Resolution of Karaoke Disputes: The Calculus of Institutions and Social Capital" (2002) 28 J Japanese Stud 301.

68 Mark D West "Losers: Recovering Lost Property in Japan and the United States" (2003) 37 Law \& Soc'y Rev 369, edited for Mark D West Law in Everyday Japan: Sex, Sumo, Suicide, and Statutes (University of Chicago Press, Chicago, 2005).

69 Mark D West Secrets, Sex, and Spectacle: The Rules of Scandal in Japan and the United States (University of Chicago Press, Chicago, 2006) 5-6.

70 For example, Ronald Gilson and Curtis Milhaupt "Choice as Regulatory Reform: The Case of Japanese Corporate Governance" (2005) 53 Am J Comp L 343.

71 For example, Curtis Milhaupt "In the Shadow of Delaware? The Rise of Hostile Takeovers in Japan" (2005) 105 Colum L Rev 2171. Other American scholars further emphasise the "internal point of view" emerging from participants in court processes: Ronald Dworkin Law's Empire (Belknap Press, Cambridge (Mass) 1986). See, for example, Kenneth L Port Japanese Trademark Jurisprudence (Kluwer Law International, London; Boston, 1998); Andrew Pardieck "The Formation and Transformation of Securities Law in Japan: From the Bubble to the Big Bang" (2001) 19 UCLA Pac Basin LJ 1; and Andrew Pardieck "Japan and the Moneylenders: Activist Courts and Substantive Justice" (2008) 17 Pac Rim L \& Pol'y J 529. Attention to black-letter law remains a powerful trend in the English law tradition, but it lost ground in top United States law schools under the influence of Legal Realism. See, for example, Luke Nottage "Tracing Trajectories in Contract Law Theory: Form in Anglo-New Zealand Law, Substance in Japan and the US" www.law.usyd.edu.au/ (accessed 1 October 2008); and Chaim Saiman "Restitution in America: Why the US Refuses to Join the Global Restitution Party" (2008) 28 Ox J Legal Stud 99. 
necessarily more messy and diffuse, and hence less susceptible to the extraction and quantitative analysis of "hard facts". ${ }^{72}$

Likewise, David Johnson's acclaimed 2002 book on Japanese prosecutors relied heavily on interviews and extensive "participant observation". This went beyond case study based approaches in exploring how organisational as well as some aspects of broader culture interact with the law in this key area of criminal justice. ${ }^{73}$ Branching out from an earlier book focusing on Japanese law and health policy, Eric Feldman drew on some statistical background for his recent study of disputes over tuna quality in Tokyo's large fish market, but he relies primarily on interviews and archival research. ${ }^{74}$ This is also true, to a lesser extent, of his ongoing work into tobacco regulation, where Feldman stresses a longstanding cultural proclivity among the Japanese towards borrowing from abroad. ${ }^{75}$

Bruce Aronson compares some summary statistics on the growth and profitability of large corporate law firms recently in Japan, the United States, the United Kingdom and Australia. But he draws heavily on media reports and some interviews in emphasising common tendencies of reputational signaling, herd behaviour and reputational status especially among "first-tier" firms in each country. ${ }^{76}$ Completing the circle, a younger American scholar (now at the University of Warwick) has recently asserted a "socio-cultural" explanation for persistently low levels of disputes resolved by arbitration in Japan. Tony Cole attempts to link Kawashima back to Eugen Ehrlich, seen as emphasising how law needed to be embedded in social relations to become effective, as well as the importance of complex networks of social groups. Cole presents no new quantitative or

72 Luke Nottage "Nothing New in the (North) East? The Rhetoric and Reality of Corporate Governance in Japan" (2006) PEP-359 Asia Pacific Economic Paper www.crawford.anu.edu.au/ (accessed 20 October 2008); abridged and updated as chapter 2 of Nottage, Wolff and Anderson, above n 23.

73 Compare, for example, Daniel Foote "The Benevolent Paternalism of Japanese Criminal Justice" (1992) 80 Cal L Rev 317 with David T Johnson The Japanese Way of Justice: Prosecuting Crime in Japan (Oxford University Press, New York, 2002), in turn reviewed by Kent Anderson "What Johnson and Schmidt Can Teach About the Japanese Curry Killer Case" (2003) 5 Austl J Asian L 90.

74 Eric Feldman The Ritual of Rights in Japan: Law, Society and Health Policy (Cambridge University Press, Cambridge, 2000); Eric Feldman "The Tuna Court: Law, and Norms in the World's Premiere Fish Market" (2006) 94 Cal L Rev 313.

75 Eric Feldman "The Culture of Legal Change: A Case Study of Tobacco Control in Twenty-First Century Japan" (2006) 27 Mich J Int'l L 743.

76 Bruce Aronson "Elite Law Firm Mergers and Reputational Competition: Is Bigger Really Better? An International Comparison" (2007) Vand J Transnat'l L 763. See also Aronson, "The Brave New World of Lawyers in Japan", above n 9. 
qualitative "empirical evidence", but instead a neo-culturalist re-reading of that presented by the early Haley as well as Ginsburg and Hoetker. ${ }^{77}$

Legal scholars mostly trained or based outside United States legal academia, especially in the Antipodes, have tended to be more eclectic in the way they go about studying Japanese law in socioeconomic context. ${ }^{78}$ As well as paying more attention to Japanese jurists' "internal point of view", reflecting the Anglo-Commonwealth sub-tradition within the common law world, ${ }^{79}$ they increasingly bring in qualitative as well as quantitative data in various forms. Leon Wolff, for example, used statistical analysis of career paths to uncover evidence of historical gender discrimination in the Japanese judiciary, but he is now complementing this with results from structured interviews. ${ }^{80}$ My work comparing Japanese attitudes and practices regarding contract negotiations included transnational surveys of students and then companies, including follow-up interviews. ${ }^{81}$ Comparisons of product liability "law in books" and "law in action" combined historical case studies with analyses of litigated and settled cases, as well as interview-based research into Japan's "PL ADR Centres". ${ }^{82}$

77 Tony Cole "Commercial Arbitration in Japan: Contributions to the Debate on 'Japanese Non-Litigiousness"' (2007) 40 NYU J Int'l L \& Pol 29, 79-80, 86-97. To extend his culturalist explanation for the lack of international arbitrations conducted with the seat in Japan, he also stresses (at 102) one American lawyer's opinion that active facilitation of settlements is pervasive and expected of arbitrators as well as judges in Japan. On the diversity of practices and views in that respect, as well as more institutional impediments, compare Luke Nottage "Japan's New Arbitration Law: Domestication Reinforcing Internationalisation?" (2004) 7 Int'l Arb L Rev 54. Compare also Gerald McAlinn "Facilitating Arbitration in Japan: Making the JCAA a Regional Centre for ADR" (2008) 20 JCA Newsletter 7, also at www.jcaa.or.jp/ (accessed 20 October 2008). For a very careful re-reading and application of Ehrlich more generally, compare David Nelken "Eugen Ehrlich, Living Law and Plural Legalities" (2008) 9 Theoretical Inquiries in Law 442.

78 Malcolm Smith "Australian Perspectives on Asian Law: Directions for the Next Decade" in Veronica Taylor (ed) Asian Laws through Australian Eyes (Law Book Company, Sydney, 1997) 3.

79 See, for example, Veronica Taylor "Continuing Transactions and Persistent Myths: Contracts in Contemporary Japan" (1993) 19 MULR 352.

80 See already Leon Wolff "Gender, Justice and the Japanese Judiciary" (2007) 5 Gender Law and Policy Annual Review (Tohoku University) 1. For a pre-emptive strike on this quantitative part of Wolff's research, see J Mark Ramseyer "Sex Bias in the Japanese Courts?" (2007) 599 Harvard Law and Economics Discussion Paper http://ssrn.com/abstract=1028080 (accessed 21 October 2008).

81 Nottage, "Planning and Renegotiating Long-Term Contracts in New Zealand and Japan: An Interim Report on an Empirical Research Project", above n 6.

82 Luke Nottage Product Safety and Liability Law in Japan: From Minamata to Mad Cows (RoutledgeCurzon, London, 2004) chapters 2 and 4 (partially updated in Luke Nottage "Comparing Product Liability and Safety in Japan: Path-Dependent Globalisation" in Harry Scheiber and Laurent Mayali (ed) Emerging Concepts of Rights in Japanese Law (UC Berkeley - Robbins Collection, Berkeley, 2007) 159); Luke Nottage and Yoshitaka Wada "Japan's New Product Liability ADR Centers: Bureaucratic, Industry, or Consumer Informalism?" (1998) 6 J Japanese L 40. 
A forthcoming book on Japanese corporate governance co-edited with Wolff and Kent Anderson, ${ }^{83}$ an American jurist trained also in Oxford and settled now in Australia, ${ }^{84}$ includes a chapter by Dan Puchniak that instead reinterprets others' recent quantitative studies of Japan's "main banks." The approach and conclusions of this young Canadian scholar, recently relocated to Singapore, cast serious doubts on Ramseyer's purported econometric proof that main banks could only have been a figment of the Marxist imagination. ${ }^{85}$ The concluding chapter in that book also includes Professor Souichirou Kozuka's general, yet highly revealing and original, analysis of key statistics illustrating the "gradual transformation" of Japan's largest companies nowadays compared to two decades ago. ${ }^{86}$

That book, and the work of its individual contributors as well as others introduced above, expressly or impliedly acknowledge the importance of some cultural elements - albeit reinterpreted and operationalised in new forms. Mark West's book comparing the comparative law and practice of scandals, for example, takes issue with broad-brush connections asserted to "national culture" ${ }^{87}$ But he uncovers how Japan differs from the United States first in preferring private ordering by various groups (an aspect emphasised by the original culturalists, and the later Haley). West also contrasts a smaller role for court processes in Japan (echoing the early Haley's emphasis on institutional

83 Nottage, Wolff and Anderson, above n 23.

84 Kent Anderson "Kent's World: A Personal Approach to the Various Worlds in Japanese Law" in Tom Ginsburg, Luke Nottage and Hiroo Sono (eds) The Multiple Worlds of Japanese Law (University of Victoria, BC Canada, 2001) 36.

85 Dan Puchniak "Perverse Rescue in the Lost Decade: Main Banks in the Post-Bubble Era" in Luke Nottage, Leon Wolff and Kent Anderson (eds) Corporate Governance in the 21st Century: Japan's Gradual Transformation (Edward Elgar, Cheltenham, 2008) 81, updating Dan Puchniak "Perverse Main Bank Rescue in the Lost Decade: Proof That Unique Institutional Incentives Drive Japanese Corporate Governance" (2007) 16 Pac Rim L \& Pol'y J 13. However, Puchniak still works within the paradigm of economic motivations and efficiency; see also Dan Puchniak "The Efficiency of Friendliness: Japanese Corporate Governance Succeeds Again Without Hostile Takeovers" (2008) Berkeley Bus L J forthcoming. Unlike West and others, he does not attempt to measure or assess culture. Nonetheless, by confirming the existence of complex institutions (like main banks) that Ramseyer's Chicago School economics does not expect to exist, Puchniak leaves us with the possibility that such institutions and their actors may also reflect some cultural values or practices.

86 Souichirou Kozuka "Conclusions: Japan's Largest Corporations, Then and Now" in Luke Nottage, Leon Wolff and Kent Anderson (eds) Corporate Governance in the 21st Century: Japan's Gradual Transformation (Edward Elgar, Cheltenham, 2008) 228. I tentatively include Professor Kozuka within the "Japanese Law" world, despite his legal training solely within Japan and his academic career there, because of his exceptionally active engagement with this world beyond nihon-ho. For a sense of this, see www.law.usyd.edu.au/anjel/content/anjel_people_prog.html and his articles reproduced at www.law.usyd.edu.au/anjel/content/anjel_research_pap.html (accessed 21 October 2008).

87 West, Secrets, Sex, and Spectacle: The Rules of Scandal in Japan and the United States, above n 69. 
barriers), despite quite protective defamation and other substantive law rules; and more divided media institutions (linking up more "elite management" accounts). ${ }^{88}$

My recent study with Kozuka comparing consumer credit also engages with all these theories. We conclude that some (significantly revised) "culturalist" elements do help to explain the growth of that credit market since the 1980s, but that a major factor comprises heuristics and biases (emphasised by "behavioural law and economics") that social psychologists have uncovered partly in Japan as well as in other contemporary societies. The process and outcomes of the latest reregulation of this market, by contrast, requires a more pluralist account of politics than elite management theory. ${ }^{89}$

We even find now work by the next generation in the "law and literature" tradition. Trevor Ryan, completing his $\mathrm{PhD}$ at the Australian National University on how law in Japan is responding to a rapidly ageing society, has already published a philosophical novel benefiting from some earlier "participant observation" of socio-legal ordering when teaching English in Japan. ${ }^{90}$ The book's Prologue vividly sets the scene with the main character, a young Australian instead called Thomas, learning of a murder - and sensing that somehow he may bear some responsibility. Most of the rest of the novel comprises Thomas' reflections back over the previous 18 months, as he settled into life in Tokyo teaching English to individuals representing a diverse cross-section of contemporary Japanese society.

Thomas abandons the strict curriculum (and many other strictures) set by the language school in favour of conversation classes revolving each time around a random selection from a book of quotations in English. These turn out to be loosely intertwined with 15 stories or parables about rules and social order submitted to Thomas' in-tray as extra homework by "Judge Ichiro", seemingly one of his adult students of similar age working as a career judge in Tokyo. Thomas responds to

88 See also Frank Upham "Privatized Regulation: Japanese Regulatory Style in Comparative and International Perspective" (1997) 20 Fordham Int'l L J 396; and Part IIA above.

89 Souichirou Kozuka and Luke Nottage "The Myth of the Cautious Consumer: Law, Culture, Economics and Politics in the Rise and Partial Fall of Unsecured Lending in Japan" in Johanna Niemi-Kiesilainen, Iain Ramsay and William Whitford (eds) Consumer Credit, Over-Indebtedness and Bankruptcy: National and International Dimensions (Hart, Oxford, 2009) forthcoming. This draws on a more descriptive comparison: Souichirou Kozuka and Luke Nottage "Re-Regulating Unsecured Consumer Credit in Japan: Over-Indebted Borrowers, the Supreme Court, and New Legislation" (2007) 07/62 Sydney Law School Research Paper http://ssrn.com/abstract=1019392 (accessed 10 October 2008) (forthcoming in the Yearbook of Consumer Law). We are currently working on a third, more normative paper that draws also on new evidence and interpretations in "cultural psychology: Dan M Kahan "Two Conceptions of Emotion in Risk Regulation" (2008) 156 U Penn L Rev 741; and Nesbitt, above n 61.

90 Trevor Ryan Dear Judge Ichiro (Zeus Publications, Burleigh, 2007). These paragraphs are based on my review in (2008) $28 \mathrm{~J}$ Studies 131. For a more elaborate view, see Souichirou Kozuka "A Foreigner's Observations on Law and Society: Reading Comparison of Legal Cultures in Trevor Ryan, Dear Judge Ichiro" (2008) 25 J Japanese L 257. 
each with his interpretation. Mostly, especially at first, these are framed by a traditional Western "rule of law" framework derived from Thomas' training as a recent law graduate from Australia. Judge Ichiro replies from a perspective on law and society that is decidedly more communitarian or hermeneutic, reflecting his own experience or at least ideals as a Japanese jurist. In Judge Ichiro's world - like Tanase's - rules, objectivism, modernity and individuals are less sharply distinguished from context, subjectivism, history and collectivities.

Thomas comes to appreciate the Judge's perspective, as well as his thought-provoking parables. This helps to explain, when the opening scene is revisited at the end of the book, why Thomas does see himself as somehow implicated in the murder, which turns out to have occurred at his language school. Even more intriguing is some suggestion that Judge Ichiro is an alter ego of Thomas himself, not a real person. An implication may be that Thomas has matured as a person, as well as a jurist, over the 18 months before returning to life in Australia.

All this work epitomises the emergent "hybrid" paradigm in Japanese Law in another sense. As well as applying more diverse methodological approaches, eschewing the grand theory characterising the other preceding paradigms, these studies tend to conclude that Japan is still not the same as "the West" - especially not the same as the United States - and that it is unlikely ever to become so. In other words, Japan is changing significantly, but only gradually and in complex ways. Meanwhile, countries, legal systems and jurists outside Japan are changing as well.

Such conclusions may not be as exciting as those reached by proponents of earlier theories of Japanese law, such as Ramseyer. Yet they seems to represent the price to be paid for a more realistic and useful paradigm for understanding Japan - and, ultimately, our own societies. It also creates more scope for cross-border academic and legal collaboration, engaging more productively with other worlds including Japanisches Recht and nihon-ho. ${ }^{91}$ After all, socio-legal studies by Tanase (and deshi such as Yoshitaka Wada) ${ }^{92}$ combine a range of empirical, theoretical and doctrinal analyses to build up a quite similar picture of Japan. Bridging academic and legal worlds will still not be easy, but Tony Angelo's career and achievements show how it can and should be done. And the work of translation, valued and promoted by him like so many jurists still in Japan, will continue to be essential as "one of the finest of victories over the difficulty of communication between people". 93

91 Luke Nottage "Japanisches Recht, Japanese Law, and Nihon-Ho" (2001) 12 J Japanese L 17.

92 Yoshitaka Wada "Merging Formality and Informality in Dispute Resolution" (1997) 27 VUWLR 45. Professor Wada was a visitor to VUW when I was Tony's colleague.

93 Kitamura, above n 5, 39 (in turn quoting a French encyclopedia author). 
